Review

\title{
The management in response to marine oil spill from ships in China: A systematic review
}

\author{
Shangao Xiong ${ }^{\mathrm{a}, \mathrm{b}}$, Hualou Long ${ }^{\mathrm{a}, *}$, Guoping Tang ${ }^{\mathrm{c}}$, Jun Wan ${ }^{\mathrm{b}}$, Hongyuan $\mathrm{Li}^{\mathrm{d}}$ \\ a Institute of Geographic Sciences and Natural Resources Research, Chinese Academy of Sciences, Beijing 100101, China \\ ${ }^{\mathrm{b}}$ Chinese Academy for Environmental Planning, Beijing 100012, China \\ ' School of Geography and Planning, Sun Yat-sen University, Guangzhou 510275, China \\ ${ }^{\mathrm{d}}$ College of Environmental Science and Engineering, Nankai University, Tianjin 300071, China
}

\section{A R T I C L E I N F O}

\section{Article history:}

Received 7 December 2014

Revised 3 May 2015

Accepted 12 May 2015

Available online 21 May 2015

\section{Keywords:}

Equipment stockpiles

Emergency response plan

Crew quality

Capability building

Coastal environmental management

Sustainable coastal development

\begin{abstract}
A B S T R A C T
Historical trends about marine ship-source oil spill incidents from 1990 to 2010 in China were analyzed, and it provided an overview of the status quo of China's management in response to marine oil spill from ships. The Chinese government has issued a series of laws on marine environmental protection since 1982, and promulgated many regulations to prevent and tackle ship-source oil spill. At present, the oil spill emergency response system established in China has five levels: the national level, sea level, provincial level, port level, and ship level. China has demonstrated its ability to control and remove small-scale oil spill from ships in port area and near-shore coastal waters, and also paid attention to related research and development projects. Although China has made significant progress in managing shipping oil spill, challenges still exist, including strengthening oil spill emergency cooperation, enhancing China's response capability, and improving relevant research and development projects.
\end{abstract}

(c) 2015 Elsevier Ltd. All rights reserved.

\section{Contents}

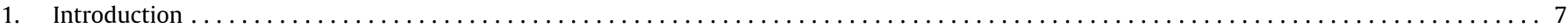

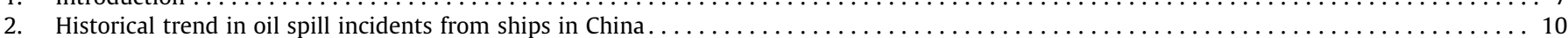

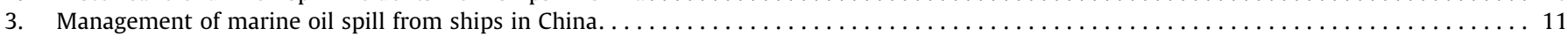

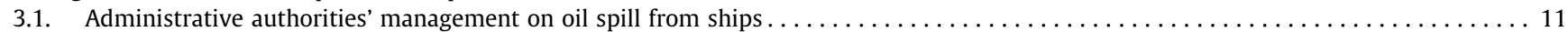

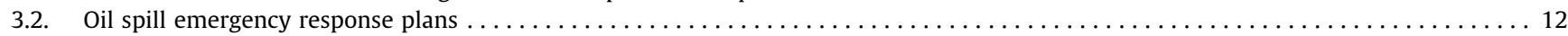

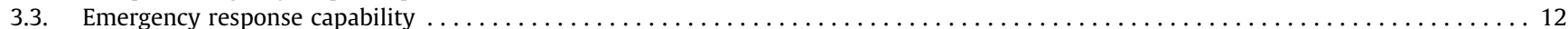

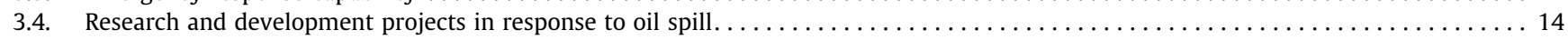

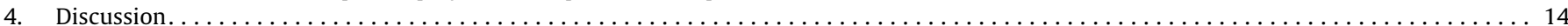

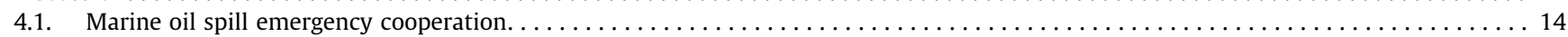

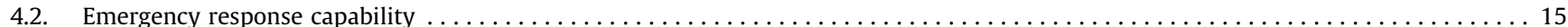

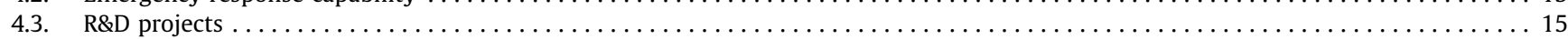

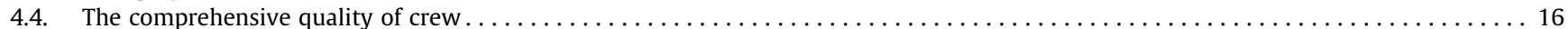

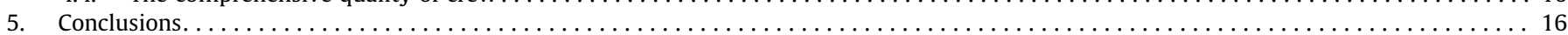

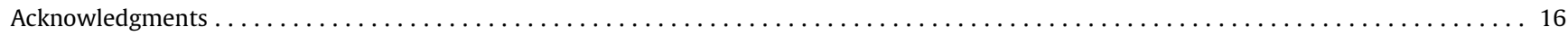

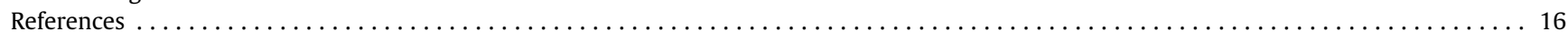

\section{Introduction}

Annually, about 5 million tons of petroleum, on average, is transported across the seas around the world. This is putting the

\footnotetext{
* Corresponding author.

E-mail address: longhl@igsnrr.ac.cn (H. Long).
}

marine lives and ecosystems at a dire risk (Anisuddin et al., 2005). Hence, the impacts of marine oil spill on marine ecosystems cannot be overlooked. In addition, marine oil spill can negatively affect local society and economy where an incident occurs (Kingston, 2002; Miraglia, 2002; Wirtz and Liu, 2006). Although marine oil spill may come from different sources, the ship-source oil spill plays a more important role in polluting marine 
environment than other marine activities such as pipelines, exploration, and production of oil (Eckle et al., 2012; Liu et al., 2015).

Marine ship-source oil spill can occur as a result of ship accidents or operations, or the intentional discharge of oily wastes into oceans (Hassler, 2011; Knapp and Velden, 2011). Among these causes, the accidental oil spill is the primary cause responsible for large spills such as collision, grounding, and hull failure (International Tanker Owners Pollution Federation Limited, 2011; Huntington et al., 2015). During the past decade, the number of large oil spills resulting from ship accidents has decreased gradually because more stringent regulations on maritime transport safety have become effective. Although the large spills were only a few, they were comprised most of oil spills occurring in the last decade. For example, there were 181 spills over 7 tons in the 2000s worldwide and these spills resulted in a total loss of 210,000 tons of oil, among which $44 \%$ was spilt in just two incidents (International Tanker Owners Pollution Federation Limited, 2011). Nevertheless, the number of small and so-called operational shipping spills is still large and increasing because of an increasing oil demand on a global basis (Radović et al., 2012). Given that incidents in deep waters are particularly difficult to cope with and the volume of oil spilled in marine environments can be extremely large (Crone and Tolstoy, 2010), it is why the international conventions on oil pollution (e.g., International Convention for the Prevention of Pollution from Ships, MARPOL; The United Nations Convention on the Law of the Sea, UNCLOS) have given special attention to the prosecution of polluting vessels (Radović et al., 2012).

Ships and vessels that may be involved in oil spills include oil tankers, bulk carriers, barges, fishing vessels, and pleasure craft. The amount of spills can be very large when released from oil tankers or small when accidentally discharged from small crafts in marinas (Garcia et al., 2013). Historically, the most serious oil spills often resulted from accidents associated with oil tankers such as the 1989 Exxon Valdez spill in Alaska, the 1999 Erika spill in France, and the 2002 Prestige in Spain (International Tanker Owners Pollution Federation Limited, 2011; Al-Majed et al., 2012). For instance, in terms of tonnage, the "Exxon Valdez" oil spill that happened in 1989 due to maritime transport by shipping was listed as the 26th largest spill in history. It was also the most expensive shipping oil spill accident in history.

The oil spill incidents resulting from oil tankers have concerned more and more coastal countries and forced them to have taken a series of measures to prevent and tackle such ship-associated pollution (Lin et al., 2013; Santos et al., 2013). For example, in order to reduce the number of oil spill accidents, to ensure the safety of navigation and to protect marine environment, the International Maritime Organization has issued a series of rules - such as the "International Convention for the Prevention of Pollution from Ships, MARPOL73/78", and the "International Convention on Oil Pollution Preparedness Response and Cooperation, OPRC 1990 (International Maritime Organization, 1973, 1990). In the United States, the "Port and Tanker Safety Act" (PTSA) was issued in 1978. This law established some rules for the inspection of foreign oil tanker equipment before they enter the US waters such that the effect of potential oil pollution on the US marine environment can be minimized. In August 1990, the US Congress passed the "Oil Pollution Act of 1990" (OPA 90). This Act mandated comprehensive oil pollution liability, compensation, prevention and response requirements. For over twenty years, the OPA 90 has played an important role in reducing the number of oil spills worldwide (Homan and Steiner, 2008). In Canada, in order to prevent and control pollution, the regulations under the "Canada Shipping Act, 2001" and the "Arctic Waters Pollution Prevention Act" set discharge limits for a variety of marine pollutants and required Canadian and foreign ships in Canadian waters to meet specified construction, equipment, reporting and operational standards.
Canada also has established a marine pollution preparedness and response system for ships. This system contains two equally important components: Canada's Marine Oil Spill Preparedness and Response Regime regulated by the Transport Canada, and the Government of Canada's operational response capability contained within the Canadian Coast Guard (part of Fisheries and Oceans Canada) (Office of the Auditor General of Canada, 2010).

China has a coastline as long as $18,000 \mathrm{~km}$ and a total coastal area of nearly 3 million square kilometers, an area that is equivalent to about $30 \%$ of China's landmass (State Council of China, 2004). China's coastal waters are ecologically diverse and rich in marine resources, including numerous species of fish, shellfish, seabirds, and mammals. These biotic resources have contributed and will continue to contribute to China's economic, social, and environmental well-being. Therefore, the occurrence of ship-source oil spill in these waters, regardless of its pollution quantity, can seriously harm China's economic, social, and environmental well-being. Although China has not experienced such large-scale oil spill incidents as the Exxon Valdez, a relatively smaller-scale oil spill incident may still bring important impacts on China's marine environment, especially when the accident occurs in ecologically sensitive areas (Sivanesan, 2013). The "Tasman Sea" oil spill incident (about 200 tons crude oil) that happened in 2002 is such a good example. This oil spill incident caused $786 \mathrm{~km}^{2}$ of the Bohai Sea to have been polluted by oil spills. It affected 1490 fishermen and farmers and resulted in a significant loss of fishery production from local fisheries. The responsible parties were charged about $\$ 5,070,000$ as compensation for these negative effects or losses in 2003 (Zhang, 2010).

In 2011, China has once again become the fastest growing energy consumption country in the globe, and the second largest consumer of crude oil in the world. The China's consumption of crude oil is about 10 million barrels per day (British Petroleum, 2012). In addition, China has about 179,200 water transport vessels with about 213 million deadweight tons (Ministry of Transport of China, 2012). The China's shipping fleet tonnage continues to be ranked as the fourth in the world. With the gradual increase in China's oil demand and vessel traffic, it increases the risk of oil spills, which pose a threat to China's marine environment. So, it is necessary to take a series of management measures in response to potential oil spill from ships in China's water. Fortunately, China has already realized the urgency of this issue and its current inadequacies in managing oil spill from ships. Through about 20 years' development till the 1990s, China has made great progress in management in response to oil spill from ships. So far, although some studies have reviewed China's management on oil spill, including establishment of laws and regulations, conducting shipping oil spill risk assessment, and developing emergency management system (Zhang, 2011; Shi, 2012; Jiang et al., 2012), most of these studies mainly focused on specific aspects of oil spill management in specific ports or seas of China. A synthesis study on China's management in response to oil spill from ships is still necessary to reduce the potential risk and protect China's marine environment.

The objectives of this study are to review the evolution and progress in China's management on oil spill from ships, discuss the status quo and problems regarding China's marine oil spill management, and provide useful information for improving China's marine oil spill management. The rest of this paper is structured to contain three main sections: the section two analyzed the historical trend in oil spill incidents from ships occurring in China; The section three reviewed China's management of marine oil spill from ships, China's oil spill emergency response plans and capability, and related R\&D projects in China; The section four discussed the future opportunities and challenges of China's oil spill management. 
Table 1

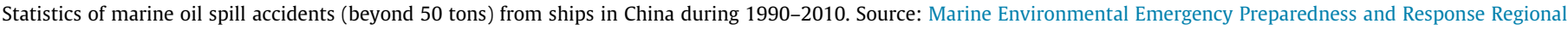
Activity Center, 2011.

\begin{tabular}{|c|c|c|c|c|c|}
\hline Date & Coordinates & Ship type & Tons & Pollutant type & Incident type \\
\hline 06/08/1990 & $38^{\circ} 30^{\prime} \mathrm{N}, 121^{\circ} 00^{\prime} \mathrm{E}$ & Cargo ship & 100 & Fuel oil & Collision \\
\hline 09/01/1992 & $37^{\circ} 30^{\prime} \mathrm{N}, 123^{\circ} 00^{\prime} \mathrm{E}$ & Cargo ship & 300 & Fuel oil & Sinking \\
\hline 10/01/1992 & $37^{\circ} 35^{\prime} \mathrm{N}, 122^{\circ} 30^{\prime} \mathrm{E}$ & Container ship & 130 & Fuel oil & Sinking \\
\hline $02 / 08 / 1993$ & $39^{\circ} 00^{\prime} \mathrm{N}, 117^{\circ} 45^{\prime} \mathrm{E}$ & Cargo ship & 50 & Fuel oil & Repair and Spill \\
\hline $05 / 22 / 1994$ & $31^{\circ} 30^{\prime} \mathrm{N}, 121^{\circ} 30^{\prime} \mathrm{E}$ & Cargo ship & 100 & Fuel oil & Fire and sinking \\
\hline 06/01/1994 & $38^{\circ} 50^{\prime} \mathrm{N}, 121^{\circ} 40^{\prime} \mathrm{E}$ & Oil tanker & 81 & Fuel oil & Collision \\
\hline 07/09/1994 & $36^{\circ} 05^{\prime} \mathrm{N}, 120^{\circ} 15^{\prime} \mathrm{E}$ & Cargo ship & 100 & Fuel oil & Collision \\
\hline $07 / 14 / 1994$ & $23^{\circ} 00^{\prime} \mathrm{N}, 117^{\circ} 00^{\prime} \mathrm{E}$ & Cargo ship & 50 & Fuel oil & Capsizing \\
\hline 08/16/1994 & $37^{\circ} 30^{\prime} \mathrm{N}, 123^{\circ} 00^{\prime} \mathrm{E}$ & Oil tanker & 100 & Fuel oil & Grounding \\
\hline $04 / 30 / 1995$ & $24^{\circ} 30^{\prime} \mathrm{N}, 118^{\circ} 30^{\prime} \mathrm{E}$ & Oil tanker & 200 & Light diesel oil & Collision \\
\hline $05 / 21 / 1995$ & $24^{\circ} 30^{\prime} \mathrm{N}, 118^{\circ} 30^{\prime} \mathrm{E}$ & Container vessel & 153 & Fuel oil & Collision \\
\hline $05 / 21 / 1995$ & $21^{\circ} 30^{\prime} \mathrm{N}, 108^{\circ} 30^{\prime} \mathrm{E}$ & Oil tanker & 144 & Fuel oil & Collision \\
\hline 06/09/1995 & $37^{\circ} 40^{\prime} \mathrm{N}, 122^{\circ} 20^{\prime} \mathrm{E}$ & Cargo ship & 410 & Fuel oil & Grounding \\
\hline 08/13/1995 & $23^{\circ} 00^{\prime} \mathrm{N}, 117^{\circ} 00^{\prime} \mathrm{E}$ & Cargo ship & 460 & Fuel oil & Hull Broken \\
\hline 08/20/1995 & $23^{\circ} 00^{\prime} \mathrm{N}, 113^{\circ} 30^{\prime} \mathrm{E}$ & Oil tanker & 700 & Crude oil & Colliding terminal \\
\hline $01 / 02 / 1996$ & $37^{\circ} 40^{\prime} \mathrm{N}, 122^{\circ} 20^{\prime} \mathrm{E}$ & Cargo ship & 150 & Fuel oil & Grounding \\
\hline $02 / 25 / 1996$ & - & Oil tanker & 632 & Crude oil & Grounding \\
\hline $03 / 08 / 1996$ & $24^{\circ} 30^{\prime} \mathrm{N}, 118^{\circ} 30^{\prime} \mathrm{E}$ & Oil tanker & 900 & Light diesel & Collision \\
\hline 05/01/1996 & - & Oil tanker & 476 & Lubricating oil & Collision and Sink \\
\hline 07/19/1996 & $31^{\circ} 30^{\prime} \mathrm{N}, 121^{\circ} 30^{\prime} \mathrm{E}$ & Oil barge & 159 & Heavy oil & Collision \\
\hline $02 / 15 / 1997$ & - & Oil tanker & 240 & Crude oil & Grounding \\
\hline 06/03/1997 & $32^{\circ} 00^{\prime} \mathrm{N}, 118^{\circ} 30^{\prime} \mathrm{E}$ & Oil tanker & 1000 & Crude oil & Explosion Fire \\
\hline $08 / 23 / 1997$ & $31^{\circ} 30^{\prime} \mathrm{N}, 121^{\circ} 30^{\prime} \mathrm{E}$ & Cargo ship & 100 & Heavy oil & Collision \\
\hline 09/17/1997 & $23^{\circ} 00^{\prime} \mathrm{N}, 113^{\circ} 30^{\prime} \mathrm{E}$ & Oil tanker & 150 & Fuel oil & Collision \\
\hline $12 / 26 / 1997$ & $23^{\circ} 00^{\prime} \mathrm{N}, 113^{\circ} 30^{\prime} \mathrm{E}$ & Oil tanker & 50 & Heavy oil & Sinking \\
\hline $01 / 20 / 1998$ & $37^{\circ} 40^{\prime} \mathrm{N}, 119^{\circ} 10^{\prime} \mathrm{E}$ & Oil tanker & 120 & Heavy oil & Sinking \\
\hline 09/12/1998 & $31^{\circ} 30^{\prime} \mathrm{N}, 121^{\circ} 30^{\prime} \mathrm{E}$ & Oil tanker & 272 & Heavy oil & Collision Sinking \\
\hline $01 / 23 / 1999$ & $31^{\circ} 30^{\prime} \mathrm{N}, 121^{\circ} 30^{\prime} \mathrm{E}$ & Oil tanker & 500 & Condensate oil & Collision \\
\hline 03/24/1999 & $22^{\circ} 30^{\prime} \mathrm{N}, 114^{\circ} 00^{\prime} \mathrm{E}$ & Oil tanker & 589 & Heavy fuel oil & Collision \\
\hline $11 / 14 / 2000$ & $22^{\circ} 00^{\prime} \mathrm{N}, 114^{\circ} 30^{\prime} \mathrm{E}$ & Oil tanker & 230 & Fuel oil & Collision \\
\hline $01 / 16 / 2001$ & $25^{\circ} 30^{\prime} \mathrm{N}, 119^{\circ} 50^{\prime} \mathrm{E}$ & Oil tanker & 2000 & Diesel oil & Stranding and capsizing \\
\hline $08 / 06 / 2001$ & $39^{\circ} 00^{\prime} \mathrm{N}, 121^{\circ} 45^{\prime} \mathrm{E}$ & Cargo ship & 200 & Light diesel oil & Collision \\
\hline $09 / 20 / 2001$ & $24^{\circ} 30^{\prime} \mathrm{N}, 118^{\circ} 00^{\prime} \mathrm{E}$ & Cargo ship & 90 & Diesel oil & Collision and sinking \\
\hline $06 / 29 / 2002$ & $47^{\circ} 00^{\prime} \mathrm{N}, 131^{\circ} 00^{\prime} \mathrm{E}$ & Oil barge & 90 & 0\# Diesel oil & Stranding and damaging \\
\hline $07 / 11 / 2002$ & $29^{\circ} 50^{\prime} \mathrm{N}, 119^{\circ} 30^{\prime} \mathrm{E}$ & Chemical tanker & 240 & Sodium hydroxide solution & Collision \\
\hline $07 / 13 / 2002$ & $31^{\circ} 30^{\prime} \mathrm{N}, 122^{\circ} 00^{\prime} \mathrm{E}$ & Oil tanker & 200 & Diesel oil & Sinking \\
\hline $09 / 11 / 2002$ & $23^{\circ} 30^{\prime} \mathrm{N}, 118^{\circ} 30^{\prime} \mathrm{E}$ & Oil tanker & 900 & Condensate oil & Stranding and catch fire \\
\hline $10 / 19 / 2002$ & $31^{\circ} 30^{\prime} \mathrm{N}, 122^{\circ} 00^{\prime} \mathrm{E}$ & Chemical tanker & 225 & Chemicals & Grounding \\
\hline $11 / 23 / 2002$ & $38^{\circ} 50^{\prime} \mathrm{N}, 118^{\circ} 26^{\prime} \mathrm{E}$ & Oil tanker & 160 & Light crude oil & Collision \\
\hline $01 / 13 / 2003$ & $35^{\circ} 28^{\prime} \mathrm{N}, 122^{\circ} 42^{\prime} \mathrm{E}$ & Oil tanker & 670 & 0\# Diesel oil & Collision \\
\hline $02 / 10 / 2003$ & $31^{\circ} 00^{\prime} \mathrm{N}, 107^{\circ} 00^{\prime} \mathrm{E}$ & Bulk chemical & 300 & Vitriol & Grounding \\
\hline $08 / 05 / 2003$ & $31^{\circ} 30^{\prime} \mathrm{N}, 121^{\circ} 00^{\prime} \mathrm{E}$ & Cargo & 85 & Fuel Oil & Collision \\
\hline $12 / 29 / 2003$ & $22^{\circ} 30^{\prime} \mathrm{N}, 114^{\circ} 00^{\prime} \mathrm{E}$ & Oil tanker & 350 & NO.4 Fuel Oil & Collision \\
\hline $04 / 06 / 2004$ & $22^{\circ} 00^{\prime} \mathrm{N}, 108^{\circ} 30^{\prime} \mathrm{E}$ & Chemical tanker & 100 & Hydrochloric acid & on the rocks and sunk \\
\hline $09 / 11 / 2004$ & $36^{\circ} 45^{\prime} \mathrm{N}, 122^{\circ} 31^{\prime} \mathrm{E}$ & Chemical tanker & 2000 & Hydrochloric acid & Overturn and sunk \\
\hline $12 / 07 / 2004$ & $22^{\circ} 06^{\prime} \mathrm{N}, 114^{\circ} 27^{\prime} \mathrm{E}$ & Container ship & 1268 & Fuel oil & Collision \\
\hline $02 / 22 / 2005$ & $34^{\circ} 37^{\prime} \mathrm{N}, 121^{\circ} 30^{\prime} \mathrm{E}$ & - & 50 & Fuel oil, lubricate oil & Capsizing \\
\hline $03 / 08 / 2005$ & $34^{\circ} 40^{\prime} \mathrm{N}, 122^{\circ} 05^{\prime} \mathrm{E}$ & Cargo ship & 50 & Fuel oil & Collision \\
\hline $03 / 08 / 2005$ & $34^{\circ} 01^{\prime} \mathrm{N}, 122^{\circ} 53^{\prime} \mathrm{E}$ & - & 50 & Fuel oil & Collision \\
\hline $04 / 08 / 2005$ & $31^{\circ} 16^{\prime} \mathrm{N}, 122^{\circ} 52^{\prime} \mathrm{E}$ & Chemical tanker & 67 & Fuel oil & Collision \\
\hline $04 / 20 / 2005$ & $24^{\circ} 30^{\prime} \mathrm{N}, 118^{\circ} 34^{\prime} \mathrm{E}$ & Cargo & 386 & 120\# Solvent oil & Collision \\
\hline $08 / 21 / 2005$ & - & Chemical tanker & 80 & Chemicals & Hull Broken \\
\hline $09 / 17 / 2005$ & $32^{\circ} 00^{\prime} \mathrm{N}, 118^{\circ} 30^{\prime} \mathrm{E}$ & Tanker & 185 & Gasoline & Collision \\
\hline $09 / 22 / 2005$ & $31^{\circ} 00^{\prime} \mathrm{N}, 118^{\circ} 30^{\prime} \mathrm{E}$ & - & 950 & Oil water & Operation errors \\
\hline $02 / 16 / 2006$ & $36^{\circ} 04^{\prime} \mathrm{N}, 120^{\circ} 19^{\prime} \mathrm{E}$ & Engineering ship & 64 & Diesel oil & Colliding terminal \\
\hline $03 / 21 / 2006$ & $28^{\circ} 39^{\prime} \mathrm{N}, 120^{\circ} 15^{\prime} \mathrm{E}$ & - & 187 & Naphtha & Collision \\
\hline $04 / 22 / 2006$ & $31^{\circ} 30^{\prime} \mathrm{N}, 122^{\circ} 00^{\prime} \mathrm{E}$ & Container ship & 477 & Heavy fuel oil & Stranding \\
\hline $05 / 03 / 2006$ & $36^{\circ} 04^{\prime} \mathrm{N}, 120^{\circ} 19^{\prime} \mathrm{E}$ & Cargo ship & 50 & Diesel oil & Collision and sunk \\
\hline $06 / 26 / 2006$ & $36^{\circ} 04^{\prime} \mathrm{N}, 120^{\circ} 19^{\prime} \mathrm{E}$ & Oil tanker & 85 & Heavy diesel oil & Collision \\
\hline $03 / 04 / 2007$ & $37^{\circ} 34^{\prime} \mathrm{N}, 121^{\circ} 30^{\prime} \mathrm{E}$ & Oil tanker & 130 & Fuel oil and diesel oil & Grounding \\
\hline $03 / 17 / 2007$ & $30^{\circ} 32^{\prime} \mathrm{N}, 123^{\circ} 15^{\prime} \mathrm{E}$ & Cargo ship & 50 & Fuel oil & Collision \\
\hline $03 / 27 / 2007$ & $38^{\circ} 14^{\prime} \mathrm{N}, 122^{\circ} 14^{\prime} \mathrm{E}$ & Oil tanker & 220 & Fuel oil & Collision \\
\hline $04 / 08 / 2007$ & $28^{\circ} 20^{\prime} \mathrm{N}, 122^{\circ} 02^{\prime} \mathrm{E}$ & Cargo ship & 50 & Fuel oil & Collision and Sinking \\
\hline $10 / 13 / 2007$ & $20^{\circ} 11^{\prime} \mathrm{N}, 110^{\circ} 24^{\prime} \mathrm{E}$ & Oil tanker & 69 & 0\# Diesel oil & Explosion \\
\hline $11 / 11 / 2007$ & $29^{\circ} 04^{\prime} \mathrm{N}, 124^{\circ} 07^{\prime} \mathrm{E}$ & Cargo ship & 50 & Fuel oil & Collision and Sinking \\
\hline $01 / 03 / 2009$ & $22^{\circ} 06^{\prime} \mathrm{N}, 113^{\circ} 50^{\prime} \mathrm{E}$ & Oil Tanker & 69 & Aviation kerosene & Collision \\
\hline $05 / 16 / 2009$ & $25^{\circ} 08^{\prime} \mathrm{N}, 119^{\circ} 18^{\prime} \mathrm{E}$ & - & 132 & Fuel Oil & Collision \\
\hline $09 / 15 / 2009$ & $21^{\circ} 53^{\prime} \mathrm{N}, 113^{\circ} 17^{\prime} \mathrm{E}$ & Container ship & 500 & Fuel Oil & Grounding \\
\hline $10 / 24 / 2009$ & $38^{\circ} 54^{\prime} \mathrm{N}, 118^{\circ} 30^{\prime} \mathrm{E}$ & Cargo ship & 70 & Fuel Oil & Collision \\
\hline $11 / 01 / 2009$ & $30^{\circ} 49^{\prime} \mathrm{N}, 122^{\circ} 37^{\prime} \mathrm{E}$ & Cargo ship & 400 & Fuel Oil & Striking reef \\
\hline $04 / 11 / 2010$ & $22^{\circ} 06^{\prime} \mathrm{N}, 113^{\circ} 38^{\prime} \mathrm{E}$ & Tanker & 90 & Cargo Oil & Collision \\
\hline
\end{tabular}

“_” Means no statistics. 


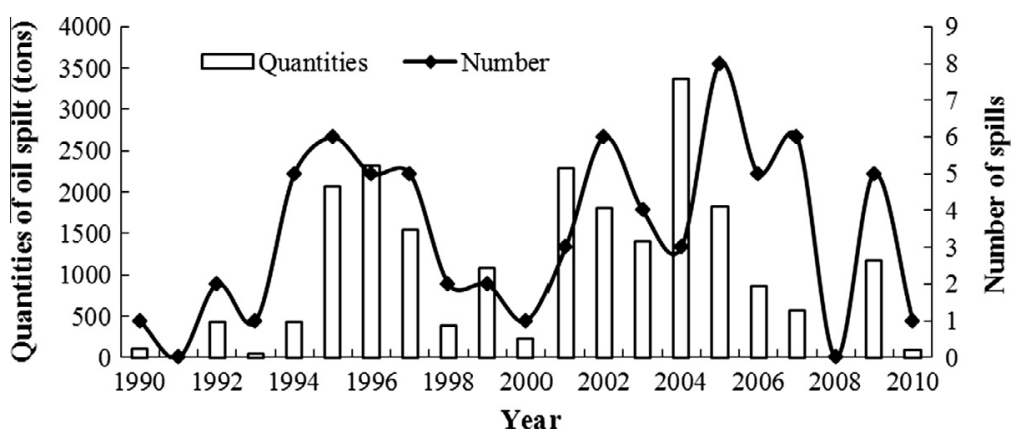

Fig. 1. Number and quantities of oil spilt (beyond 50 tons) in various years (generalized from Table 1).

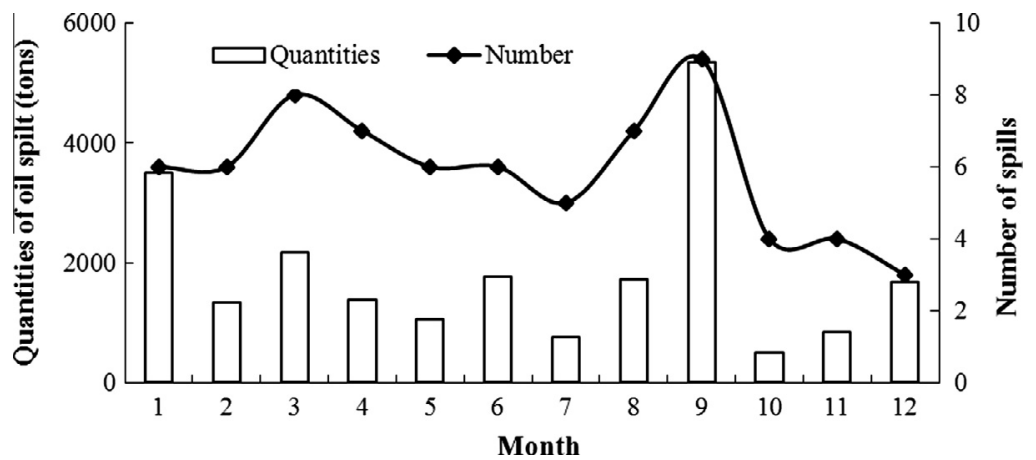

Fig. 2. Number and quantities of oil spilt (beyond 50 tons) in various months (generalized from Table 1).

\section{Historical trend in oil spill incidents from ships in China}

To understand the trend in oil spill incidents, the historical oil spill incidents from ships in China during 1990-2010 were collected and listed in Table 1.

From 1990 to 2010, about 22,035 tons of oil was lost to China's water as a result of tanker incidents. The loss averaged 1049 tons spilt per year (Fig. 1) and the number of spills beyond 50 tons was 71. Annually, the rates of occurrence were about three spills per year, which was higher than the global average (International Tanker Owners Pollution Federation Limited, 2011). Among 71 accidents, two of the biggest oil spills (beyond 2000 tons spillage) occurred in 2001 and 2004, respectively (Fig. 1). Apparently, the number of spills incidents changed significantly during 19902010. The quantities of oil spilt were generally positively correlated with the number of oil spills. The oil spills occurred more frequently in two sub-periods: one was from 1994 to 1997 and another was from 2002 to 2007 (Fig. 1).
Monthly, the inter-monthly variability of oil spilt was not significant (Fig. 2). In contrast, oil spills generally occurred more frequently during the period from January to September than from October to December (Fig. 2). This may be a result of related weather condition. Huang et al. (2011) reported that the sea fog in China's Yellow Sea areas begins to increase gradually from March to September. After September, the occurrence of sea fog is relatively less. During 1990-2010, the quantities of oil split reached highest in September, followed by January, and fluctuated in other months (Fig. 2).

Based on the causes of shipping oil spills, the oil spill incidents can be divided into operational incidents and accidents. The operational oil spills consist of loading/discharging, bunkering, ballasting, de-ballasting, and tank cleaning. The operational incidents are the main causes responsible for small and medium sized spills (below 7 tons), In contrast, the operational accidents, which consist of collisions, groundings, hull failures, fire and explosion, are the major causes responsible for large sized oil spill (beyond 7 tons)

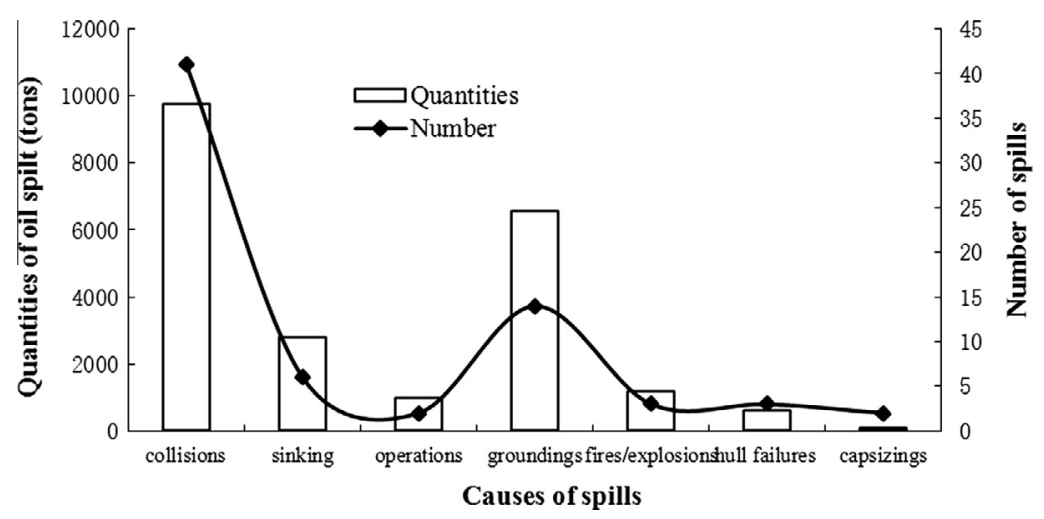

Fig. 3. Number and quantities of oil spilt (beyond 50 tons) because of different causes (generalized from Table 1). 
Table 2

Laws and regulations of government on marine oil spill management in China.

\begin{tabular}{|c|c|c|}
\hline Laws and regulations of government & Issuer & Date implemented \\
\hline \multicolumn{3}{|l|}{ Laws } \\
\hline Marine environmental protection act of China & National People's Congress of China & $\begin{array}{l}1982 \text { (revised in } \\
2000 \text { ) }\end{array}$ \\
\hline Maritime traffic safety act of China & National People's Congress of China & 1984 \\
\hline Maritime act of China & National People's Congress of China & 1993 \\
\hline Port act of China & National People's Congress of China & 2004 \\
\hline Tackling emergency affairs act of China & National People's Congress of China & 2007 \\
\hline \multicolumn{3}{|l|}{ Regulations } \\
\hline Regulations on the prevention of marine pollution management of China & The State Council of China & $\begin{array}{l}1983 \text { (abolished in } \\
\text { 2010) }\end{array}$ \\
\hline Rules for waterway transport & Ministry of Transport of China & 1997 \\
\hline Regulations on the safety supervision and management of Ro-Ro ship & Ministry of Transport of China & 2002 \\
\hline National environmental emergency contingency plans & The State Council of China & 2006 \\
\hline Regulations on configuration of national marine oil spill emergency equipment stockpiles & Ministry of Transport of China & 2009 \\
\hline $\begin{array}{l}\text { Notices on implementation plan of obsoleting single-hulled oil tankers domestic voyage in } \\
\text { advance }\end{array}$ & Ministry of Transport of China & 2009 \\
\hline Regulations on the prevention and controlling marine pollutions from shipping & The State Council of China & 2010 \\
\hline $\begin{array}{l}\text { Interim procedures on emergency plan management for abrupt environmental pollution } \\
\text { accidents }\end{array}$ & Ministry of Environmental Protection of China & 2010 \\
\hline Implementing measures on civil liability insurance of oil pollution damage from ships & Ministry of Transport of China & 2010 \\
\hline $\begin{array}{l}\text { Regulations on the prevention and controlling management of marine environmental pollution } \\
\text { by ship and related activities }\end{array}$ & Ministry of Transport of China & 2011 \\
\hline $\begin{array}{l}\text { Regulations on emergency preparedness and emergency management for marine environment } \\
\text { pollution by ships }\end{array}$ & Ministry of Transport of China & 2011 \\
\hline Regulations on the collection and used of oil pollution damage compensation fund by ships & $\begin{array}{l}\text { Ministry of Transport of China and Ministry of } \\
\text { Finance of China }\end{array}$ & 2012 \\
\hline
\end{tabular}

(International Tanker Owners Pollution Federation Limited, 2011). For example, collisions and grounding/stranding accounted for $59 \%$ and $20 \%$ of the shipping oil spills during 1990-2010, respectively (Fig. 3).

Therefore, collisions and grounding/stranding are the two major types of causes of oil spill from ships, consistent with ITOPF's research on the global shipping oil spill incidents. According to this finding, specific measures that can be adopted to reduce the occurrence of oil spill incidents may involve improving navigation conditions and the channel status as well as enhancing ship's crew operational capacity (Otero et al., 2014).

\section{Management of marine oil spill from ships in China}

\subsection{Administrative authorities' management on oil spill from ships}

To meet the challenges of oil spill management and to gradually conform to related international convention requirement, the Chinese government has issued a series of laws and regulations on marine environmental protection since 1982 (Table 2). In 1982, the National People's Congress of China issued the "Marine Environmental Protection Act", which was the first official law related to oil spill (National People's Congress of China, 2000). This law was amended in 2000. In order to implement the law, the State Council issued the "Regulations on the prevention of marine pollution management of China" in 1983, which symbolized the first step in China's environmental management of ship pollution to marine. In 2010, the State Council promulgated the "Regulations on the prevention and controlling marine pollutions from shipping" (State Council of China, 2010), and the new regulation described in detail on how to prevent the pollutants from ship emissions, arrange emergency disposal of pollution incidents from ships, conduct investigation and handling of pollution accident, and make compensation for pollution accident.

According to the "Regulations on the prevention and controlling marine pollutions from shipping" in 2010, several departments are responsible for managing shipping in China's water while each takes charge of different waters. Currently, the Maritime Safety
Administration, a member of the Ministry of Transport of China, is mainly responsible for environmental management of shipping oil spill. It is the main agency overseeing the supervision and enforcement of related laws at the national level. This department is also in charge of non-military vessels in harbor waters under its jurisdiction as well as non-military and non-fishing vessels outside harbor waters. The Bureau of Fisheries is responsible for ship pollution management associated with non-fishing ships in fishing port and fishing vessels outside the fishing port waters. The environmental protection department of the China's army is responsible for the supervision and management of military ship pollution accidents.

In 2009, the Ministry of Transport issued the "Notices on implementation plan of obsoleting single-hulled oil tankers domestic voyage in advance". This regulation responded actively to the international convention concerning "International Convention for the Prevention of Pollution from Ships (MARPOL73/78)" (Ministry of Transport of China, 2009), and has contributed to the reduction of risk of major oil pollution accidents. In the past, the damage compensation mechanism for ship-source pollution accidents was incomplete in China, which made victims difficult to gain enough compensation and clean-up oil pollution in time. This situation has changed since 2010 in which the Ministry of Transport issued the "Implementing measures on civil liability insurance of oil pollution damage from Ships". This regulation was the first official regulation related to the shipping insurance of civil liability for oil pollution damage (Ministry of Transport of China, 2010). To further improve the compensation mechanism, the Ministry of Finance and the Ministry of Transport jointly issued the "Regulations on the collection and use of oil pollution damage compensation fund by ships" in 2012 to address the collection, use and management of compensation fund (Ministry of Transport of China and Ministry of Finance of China, 2012). The establishment and implementation of this regulation promoted the development of China's marine oil pollution damage compensation mechanism. As a result, it was regarded as one of important landmarks in the progress of management in response to oil spill from ships in China. 


\subsection{Oil spill emergency response plans}

The China's ship oil spill emergency response plans took effect in the early 1990s while such activities had been developed vigorously outside China. In 1983, China acceded to the "MARPOL73/78" (the International Convention for the Prevention of Pollution from Ships, 1973 as modified by the Protocol of 1978) (Zhang, 2011). According to the requirements of this convention, China drew up the "Ship Oil Pollution Emergency Plan" for international routes in 1995, and for domestic routes in 1996 (State Environmental Protection Administration and Ministry of Transport of China, 2000). In 1998, China acceded to the convention of OPRC90. In order to meet related requirements in the OPRC90, the Ministry of Transport and the State Environmental Protection Administration jointly issued and implemented the "China Marine Ship Oil Spill Emergency Response Plan", the "China's Northern Seas Oil Spill Emergency Response Plan", the "East China Sea Oil Spill Emergency Response Plan", the "South China Sea Oil Spill Emergency Response Plan", and the "Waters of the Taiwan Strait Oil Spill Emergency Response Plan" in 2000 (State Environmental Protection Administration and Ministry of Transport of China, 2000). In 2001, the "Ship Marine Pollution Emergency Plan" was also formulated for ships carrying toxic and hazardous liquid chemicals. Thereafter, the emergency plans were carried out across the country at all levels under the guidance of these plans. In 2004, to meet the requirements of the relevant contingency plans for emergencies, the Ministry of Transport issued the "China's National Waters Ship Pollution Emergency Plan" on the basis of the "China Marine Ship Oil Spill Emergency Response Plan" (Lao et al., 2009). In this new plan, the areas to which the China's National Waters Ship Pollution Emergency Plan is applicable were expanded from sea to all waters. The types of pollutants applicable to this plan involved toxic and harmful chemicals besides oil. Under its guidance, as of August 2009, the local governments had issued and enforced ship pollution emergency plans in 58 coastal cities and 9 coastal provincial regions such as Shanghai, Tianjin, Hebei, Shandong and Zhejiang (Lao et al., 2009). At present, there exist five-level oil spill emergency response systems, including the national level, sea level, provincial level, port level, and ship level (Fig. 4) (Zhao, 2005).
At present, it becomes more and more important to establish bilateral oil-spill response regime to provide mutual assistance in combating accidents caused by oil pollution around the world (Sydnes and Sydnes, 2013). China has realized that the international cooperation and assistance are crucial for the successful management on oil spill pollution, especially facing a major oil spill accident that occurs on the high seas (Lu, 2012). Therefore, China has been taking an active part in international cooperation in response to marine oil spill emergency. In 2004, to better fulfill the international convention and enhance the international communication and collaboration, China, Japan, Russian and South Korea jointly formulated the "North-West Pacific Action Plan-Regional Oil Spill Contingency Plan", signed the "memorandum of understanding on regional cooperation for North-West Pacific marine environment oil spill preparedness and response", and set up oil spill emergency action mechanism of cooperation and mutual aid (Lao et al., 2009). In 2007, the Marine Safety Administration of China, the International Maritime Organization and the International Petroleum Industry Environmental Protection Association jointly signed a letter of intent of maritime environment protection (Maritime Safety Administration of China, 2012a). One of important contents of the letter is about strengthening regional cooperation among international maritime organizations, national authorities and enterprises in response to oil spill emergency.

\subsection{Emergency response capability}

Currently, the function of China's emergency response capability mainly includes the response resources allocation, the response personnel training and the emergency response exercises. China's emergency resources allocation began in 1974 when the Ministry of Transport built a batch of oil sewage ponds of 1-2.5 ten thousand cubic meters to dispose ship ballast water at the ports of Dalian, Qinhuangdao, Qingdao, Nanjing and Zhanjiang (Lao et al., 2009). From the late 1990 s to the early 21 st century, with the rapid development of economy and environmental protection in China, the industry of ship oil spill emergency resources began to emerge widely in China (Table 3). For example, the oil containment booms, the oil sorbent materials and the oil spill dispersants increased

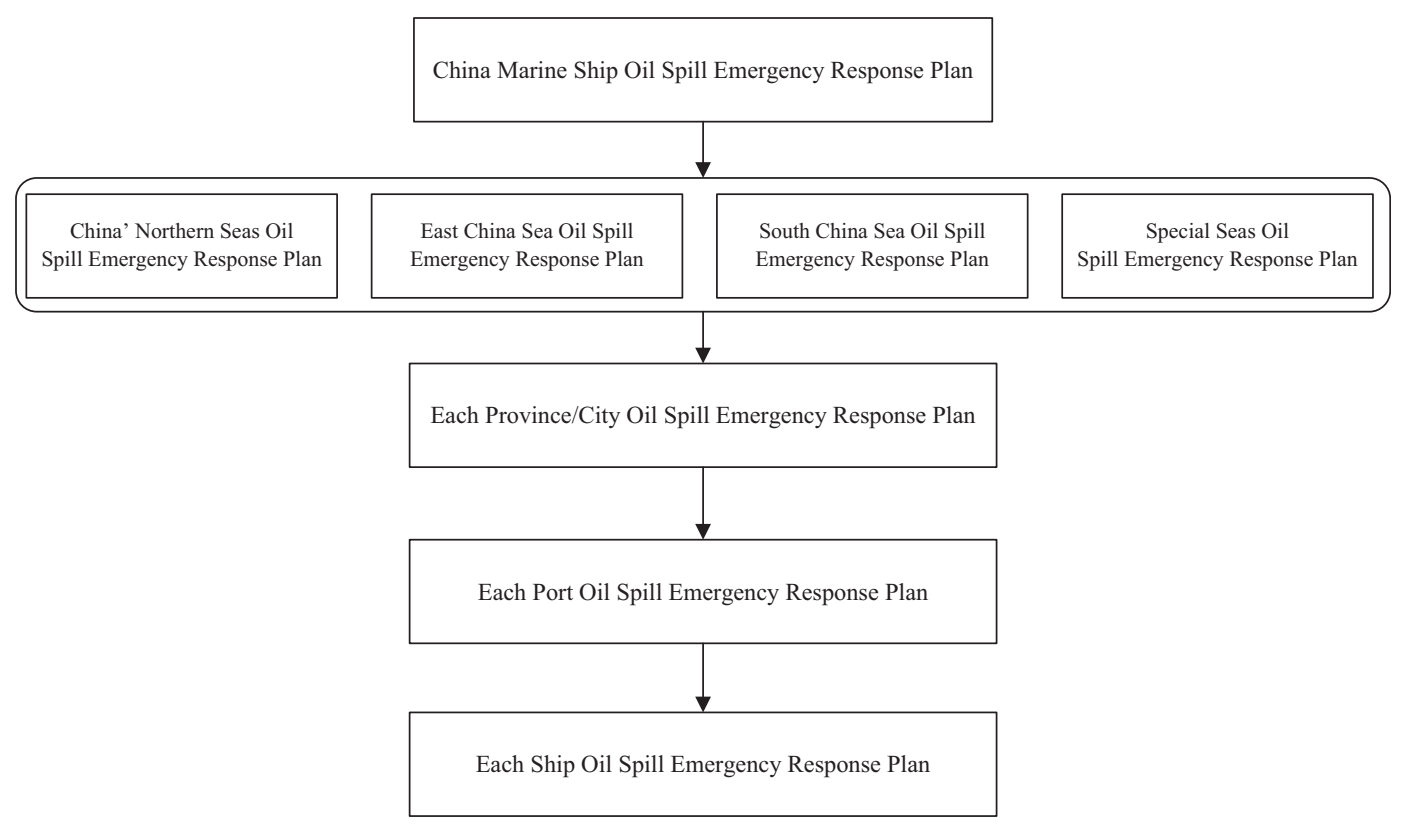

Fig. 4. Five-level oil spill emergency response system in China. 
Table 3

Clean-up materials for oil pollution in China's coastal regions. Sources: Lao et al., 2009; Maritime Safety Administration of China, 2012a.

\begin{tabular}{|c|c|c|c|c|c|}
\hline Year & $\begin{array}{l}\text { Oil containment } \\
\text { booms }(\mathrm{m})\end{array}$ & $\begin{array}{l}\text { Oil skimmer } \\
\text { machines }\end{array}$ & $\begin{array}{l}\text { Ships for oil recovery and } \\
\text { laying oil containment booms }\end{array}$ & Oil sorbent materials $(\mathrm{kg})$ & Oil spill dispersants ( $\mathrm{kg}$ ) \\
\hline 2000 & 109,805 & 77 & 142 & 74,410 & 93,865 \\
\hline 2008 & 280,000 & 253 & 300 & 502,000 & 589,000 \\
\hline
\end{tabular}

rapidly during 2000-2008. Meanwhile, China's major coastal ports have basically met the emergency response capacities for controlling and removing small-scale oil spill in port area and near-shore coastal waters.

In 2007, the National Development and Reform Commission and the Ministry of Transport jointly issued the "Layout Planning of National Water Traffic Safety Supervision and Rescue System" (National Development and Reform Commission of China and Ministry of Transport of China, 2007). Based on the distribution of national crude oil transportation network and ocean sensitive resource area, this plan insisted that sixteen national oil spill emergency equipment stockpiles should be set up in China's coastal areas (Fig. 5), comprising four large-scale equipment stockpiles, five medium-scale equipment stockpiles and seven small-scale equipment stockpiles (National Development and Reform Commission of China and Ministry of Transport of China, 2007). The large-scale, medium-scale, and small-scale equipment stockpiles are able to cope with 1000 tons, 500 tons, 200 tons oil spillage at a time, respectively (Ministry of Transport of China, 2008). So far, about 13 emergency equipment stockpiles have been completed (Bei, 2013) and the rest are under transformation and construction. Meanwhile, China has initially established a professional emergency team for managing, controlling and cleaning-up oil spill. As of October 2012, the Maritime Safety Administration of
China has examined and approved 138 clean-up companies for pollution in China's coastal regions (Maritime Safety Administration of China, 2012b).

The emergency training is the systematic acquisition of knowledge, skills, and attitudes in order to develop competencies necessary for effective performance in accidental environments (Sinclair et al., 2012). To achieve this end, the maritime safety administrations organizes the emergency trainings in coastal ports every year since the Ministry of Transport held the first international oil pollution emergency training courses in Beijing in 1980, which trained a group of oil spill response command personnel and clean-up workers. According to statistics, there are 897 on-scene commanders and 646 senior commanders for ship oil spill emergency response to have taken the training courses (Oil Spill Prevention and Response Net, 2012). In addition, China also attaches great importance to emergency exercises for oil spill because emergency exercising can help test the knowledge, skills, and the abilities of first responders and government officials, and assess participant perceptions of teamwork, training adequacy, response network effectiveness, job risk, and equipment adequacy (McEntire and Myers, 2004). In recent years, the Ministry of Transport has organized many large-scale marine oil spill emergency exercises in coastal areas of Shanghai, Qingdao, Hainan, Zhujiang, Qinhuangdao and etc. For example, the "Joint search-and-rescue

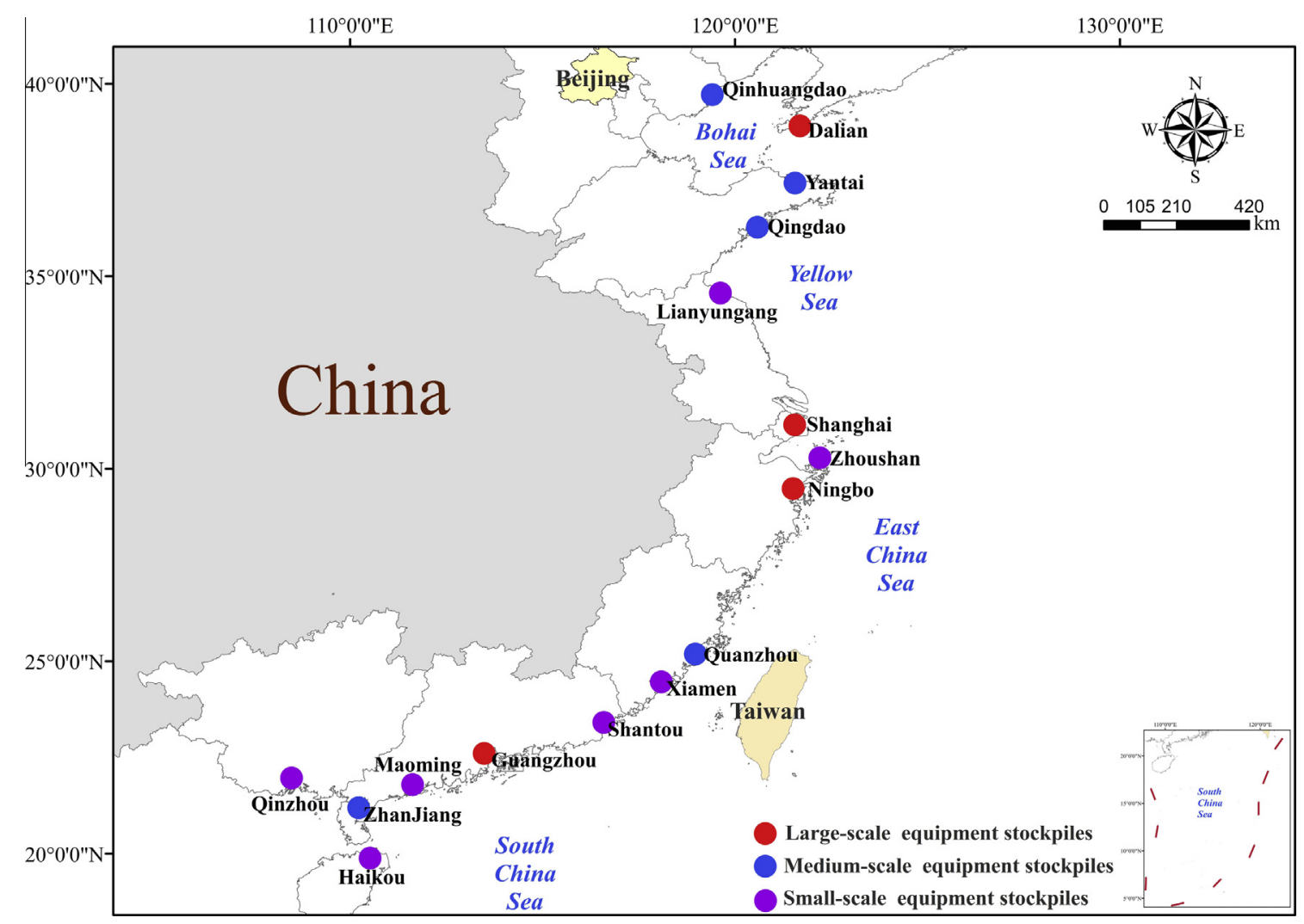

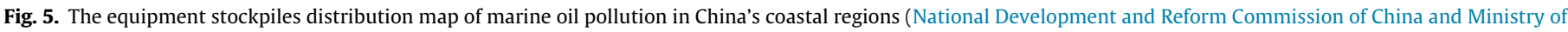
Transport of China, 2007). 
Table 4

Different subjects of R\&D projects on marine oil spill from 2001 to 2012 in China. Sources: China Academy of Transportation Science, 2013; National Natural Science Foundation of China, 2013.

\begin{tabular}{llc}
\hline Topic & Subject & R\&D projects \\
\hline Contingency planning & Response & 31 \\
& Risk analysis & 2 \\
& Modeling & 6 \\
Response techniques & Dispersants & 1 \\
& Mechanical recovery & 7 \\
& Clean-up activities & 8 \\
Impact assessments & Human health impact & 0 \\
& Environmental impact & 8 \\
& Socio-economic impact & 2 \\
& Total & 65 \\
\hline
\end{tabular}

exercise in the South China sea", the "Joint search-and-rescue exercise in the East China Sea", the "Joint search-and-rescue exercise in the Dalian", the "Oil spill emergency exercise in Bohai Sea" and the "China and South Korea oil spill emergency exercise" were held in 2004-2008, respectively (Xu, 2009).

\subsection{Research and development projects in response to oil spill}

Given the economic value, ecological importance and security considerations, there is an increasing need for a better protection of the world's marine ecosystems through the implementation of new or improved spill prevention mechanisms and emergency response systems, which involve the operational forecasting, the risk and damage assessment, the restoration measures and the monitoring activities (Garnacho et al., 2010). Therefore, scientific decisions based on above mentioned prevention mechanisms and response systems are indispensable for effective spill prevention and response. In order to better integrate science and technology into spill response mechanisms and decision-making systems, to enable the adaption of best operational practices, and to maximize the outputs from existing efforts, China has made efforts to improve the national strategic planning of R\&D activities on marine oil spill pollution. Due to the limitation of earlier data, this paper only analyzes marine oil spill R\&D projects from 2001 to 2012 (Table 4). During this period, the total number of R\&D projects was 65 , indicating that China has embarked on the fast track of research and development in environmental management of marine oil spill from shipping. Preparedness, response and impact assessment are generally three main R\&D topics and each includes different subjects. Presently, China has the broad scope of marine oil spill R\&D projects for effective spill prevention and response. The highest proportion (60\%) of R\&D projects was found to be related to contingency planning, followed by response techniques

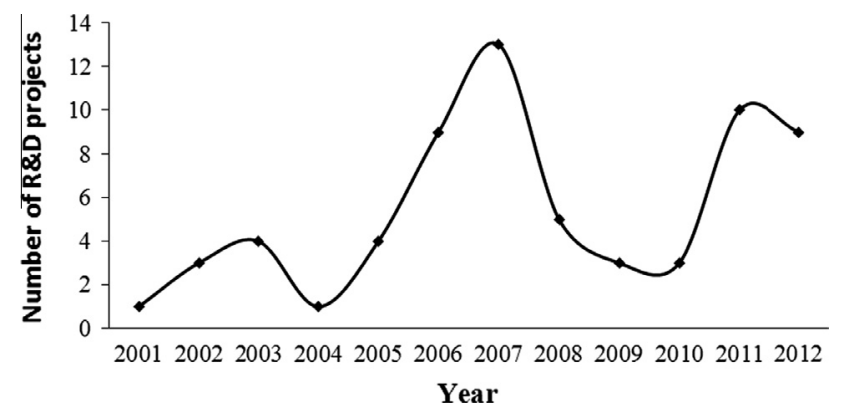

Fig. 6. Number of R\&D projects on marine oil spill from 2001 to 2012 in China (China Academy of Transportation Science, 2013; National Natural Science Foundation of China, 2013).
(25\%) and impact assessment (15\%). Most R\&D projects are related to response in the contingency planning projects. Mechanical recovery and clean-up activities are the main focus in the response techniques projects (Chen et al., 2013). Few R\&D projects addressed socio-economic and especially human health impacts. This concerned the government and public because the socio-economic aspects are important concerns in most major incidents while human health is more likely to be seriously impacted by large chemical spills in or close to urban areas than by oil spill (Wei et al., 2015). The influence of major spills on the funding of $R \& D$ that deals with accidental marine pollution is significant. In a sense, R\&D effort generally decreases as the elapsed time increases since the last major incident. For instance, the China's historical oil spill incidents reached highest during the period of 2002-2007 (Fig. 2). Correspondingly, the number of R\&D projects also reached highest in 2007 and then it declined gradually till 2010 (Fig. 6), after which it started increasing again till 2011 as a result of the ConocoPhillips oil spill incident occurring in June of 2011. Overall, the marine oil spill R\&D projects in China have progressed greatly in recent years and the consequent results have been gradually put into practice. For example, Satellite Remote Sensing, the Beidou Navigation Satellite System and the Automatic Identification System (AIS) have been used to monitor marine oil spill (Shi, 2012). The migration model of marine oil spill is currently an important component of the emergency decision-making support system. Twenty vessel traffic systems (VTS) have been constructed in the coastal region and the Yangtze River downstream (Shi, 2012). In 2007, China's first aviation remote sensing monitoring system for marine oil spill has been successfully developed by Guangdong Maritime Safety Administration and Dalian Maritime University (Luo, 2008). The R\&D activities have provided a strong support for preventing and responding to oil spill in China.

\section{Discussion}

China has made outstanding achievements in managing marine oil spill from ships. However, limitations still exist and need to be addressed in the future.

\subsection{Marine oil spill emergency cooperation}

Currently, China has not yet established a complete national oil spill response command system (Wang and Dong, 2010). The oil spill emergency response coordination and command basically relies on the Maritime Safety Administration. The response to marine oil spill from ships, especially in a major oil spill accident, will involve the active collaboration among a number of emergency departments. Although the marine oil spill emergency response system, especially the "oil spill contingency plan", clearly defined the responsibilities and obligations of each participating entity and emphasized the collaboration among them. However, with an exception of the Maritime Safety Administration, the rights and responsibilities of other departments are vague in practice. As a result, the collaboration among different departments is often temporary and weak in the process of on-site disposal of the accident, especially when dealing with accidental emergency. At the same time, China's current emergency response systems are managed in accordance with the sub-sector and single hazard compartmentalization, such as earthquake resistance and hazardous reduction, marine search and rescue, and so on. The oil spill emergency response system and others have not yet implemented the effective information interconnection and resource sharing. Once a serious oil spill accident happens, it becomes very difficult to have the aid from other professional emergency forces. Even when 
there is a need to obtain the permit and support from other professional emergency forces, the coordination process is time-consuming and difficult. The U.S. oil spill emergency command system comprises 16 government departments such as the U.S. Coast Guard, the Federal Environmental Protection Agency, the National Oceanic and Atmospheric Meteorological Bureau, the Ministry of the Interior, the Ministry of Communications, the Ministry of Agriculture, and the Department of Energy (Department of Crime Control and Public Safety Division of Emergency Management, 2010). Although each of these departments has its own role and responsibility, some of their duties may overlap. To solve this problem, according to the Oil Pollution Act of 1990, a permanent organization-Oil Spill Prevention and Response Office was established in the national and state governments of oil spill emergency command system. The members of this office are from different government departments of liability for oil spill prevention and response. The existence of the standing body strengthens the collaboration among different governmental departments, and gives full play to the staff and resources advantage such that the emergency response can be performed more quickly and coordinated easily among different departments (Department of Crime Control and Public Safety Division of Emergency Management, 2010). Such active collaboration has already taken effects in "Deepwater Horizon" oil spill accident, and is worthwhile learning for China. In the future, the cooperation had better be conducted in the following three major aspects. First, all departments should establish information reporting system for disseminating accident information among different departments in a timely manner. Second, all departments should strengthen the resource sharing, to reduce the waste of national resources and to improve the efficiency of pollution accident treatment. Third, all departments should attach importance to the accident information released, to make victims know information in time, and to avoid possible social contradictions.

\subsection{Emergency response capability}

At present, some local governments in the coastal regions are still focusing solely on the economic development but neglect the management of marine oil spill pollution. As a result, related emergency power is insufficient. Meanwhile, the emergency response mechanism in which the government should play a dominant role while the society should actively participate has not yet fully established. Especially in high-risk areas of oil spill such as the Yangtze estuary, the Pearl River estuary, the Taiwan Strait and the Bohai Bay, the national major emergency forces have not been established. Although the state and local governments have established some emergency equipment stockpiles, these emergency resources can only deal with small-scale oil spill pollution accidents occurring in ports and near-shore waters. At the global scale, the clean-up pollution rate of international ship oil spill accident has reached more than $70 \%$. In China, however, it is only $7 \%$ (Zhang, 2011). In the future, local governments and relevant administrative departments should emphasize the safety and environmental awareness. So, China should speed up the pace of developing national emergency equipment stockpiles based on the differences of oil spill risk in coastal regions. In addition, the Maritime Safety Administration should strengthen reconstruction of buoy tender and navigation marks to meet the needs for ship navigation and environmental management in important sea areas. Relevant administrative departments should take concrete measures to encourage and support social forces to participate oil spill accidents prevention and clean-up operations. In the view of foreign experiences, social forces can be the main part of the oil spill emergency response forces. Therefore, China should set up a relatively perfect market circumstances. For instance, it is important to improve the mechanism of pollution damage compensation and set up the mechanism of emergency services so that the social forces can be on the path of market-oriented operation. Although, China began to impose oil pollution damage compensation fund on the compensation of oil pollution damage and related cost in 2012, it is still a long way to go to put it into full effect. The oil spill emergency exercise is the best way for testing all aspects in emergency response in order to improve the deficiency of existing oil spill emergency response system. Hence, the maritime safety administrations should organize training courses for the oil spill emergency response, and have social forces involved in oil spill emergency exercises.

\subsection{RED projects}

For marine oil spill management, science and technology such as remote sensing are essential for management agencies to make timely decision and effective response when an oil spill accident happens (Fingas and Brown, 2014; Xu et al., 2014). Compared with the current development and actual requirement, although the $R \& D$ activities in China have been rapidly developed in recent years, there are still shortcomings that need to be addressed in the future. First, the proportion of mechanical recovery projects only accounted for $11 \%$ of R\&D projects at this stage and the development of oil spill removal facilities has been relatively slow. For example, the United States has built the national oil spill response test facility (Ohmsett), which was the world's largest tow/wave tank designed to evaluate the performance of equipment that detects, monitors and clears up oil spill under environmentally safe conditions (Mullin and Lane, 2000). In contrast, China has not had such a specialized testing institution. In addition, most of the oil skimmer equipment is used only in controlling oil spill recovery area and cannot restrain the ocean wave disturbance. As a result, the efficiency of clean-up operation is often unsatisfactory. It is therefore necessary to strengthen research to meet the needs of equipment inspection and experimental conditions. For instance, based on the Yantai and Qinhuangdao Oil Spill Emergency Response Center, the research and development of oil removal equipment should be improved to function well enough under heavy weather and particular topography. Second, there were eight environmental impact projects on marine oil spill in China from 2001 to 2012, which were more than the socio-economic impact projects (two projects) and the human health impact projects. Human health is more likely to be seriously impacted by large chemical spills in or close to urban areas than by oil spill (Noh et al., 2015). A major oil spill event can exert long-term effects on the socio-economic development in a region, therefore, a holistic assessment that includes the impacts of oil spill on environment, socio-economy and human health is necessary and essential. Third, the oil spill monitoring ability is relatively weak in China. There are only six R\&D projects concerning the monitoring and modeling of oil spill trajectories. The lack of R\&D program investment and the inadequacy of modernization of the remote sensing and aerial monitoring in all sea areas need to be addressed (Zhang, 2011). The discovery of oil spill incidents almost completely relies on the report of ships and the detection of the oil spill trajectory mainly relies on visual surveillance by patrol boats. Hence, the oil spill emergency monitoring and prediction system is not adequate and need to be improved. Through investing in the software research and development, the monitoring system of aviation, navigation, radar and satellite remote sensing detection should be set up in all sea areas to achieve stereoscopic monitoring in all-time and all-weather. In addition, the scope and precision of prediction models for oil spill should be improved to allow scientific and timely decisions on oil spill emergency (Xu et al., 2013). 


\subsection{The comprehensive quality of crew}

Based on historical data, $79 \%$ of serious ship oil spill incidents were caused by collisions and groundings (Fig. 3). Human error is one of the main causes leading to a collision incident. This suggests that there are still deficiencies in crew's security awareness, operation ability, judgment and comprehensive evaluation ability (Karahalios, 2014). So, the relevant management departments should pay more attention to the improvement of the crew's comprehensive quality, and make them regularly take part in pollution prevention knowledge and skills training. To meet the requirements of the safety management system, the anti-pollution equipment operation training should be regularly organized for crew. Meanwhile, it is important to place special emphasis on professional moral accomplishment of the crew, especially the driver, so that they can develop good safety awareness and abide by sailing regulations and safe operating procedures. The maritime authorities should transform the traditional theory on management into assessing the actual operation ability of crew. In addition, the monitoring and control system of crew qualifications should also be established.

\section{Conclusions}

China is a country with vast maritime territory that is extremely abundant in sea resources. With the rapid socio-economic development, oil demand in China has increased greatly and the resultant vessel traffic also takes on a fast growth. Correspondingly, the risks of ship oil spill have also increased. Currently, China is endeavoring to make the laws and regulations for preventing and controlling marine oil spill, enhance emergency response capability, and accelerate the pace for R\&D activities. Although China is making progress in managing marine oil spill from ships, there are still inadequacies in fighting oil spill from ships. In the future, these weaknesses such as lack of the monitoring and control system of crew qualifications need to be improved and strengthened such that the safety of navigation and the protection of marine environment can be ensured.

\section{Acknowledgments}

This work was supported by the National Natural Science Foundation of China (Grant Nos. 41130748 and 41171149) and by the One-Hundred Talented Program in Sun Yat-sen University.

\section{References}

Al-Majed, A.A., Adebayo, A.R., Hossain, M.E., 2012. A sustainable approach to controlling oil spills. J. Environ. Manage. 113, 213-227.

Anisuddin, S., Al-Hashar, N., Tahseen, S., 2005. Prevention of oil spill in seawater using locally available materials. Arab. J. Sci. Eng. 30 (2B), 143-151.

Bei, S., 2013. The capacity of the country for emergency response to major maritime oil spill greatly promoted. China Marit. Safe 1, 61-62.

British Petroleum, 2012. BP statistical of world energy. <http://www.bp.com/ productlanding.do? categoryld $=9041910$ andcontentId=7075397> $\quad$ (accessed 28.10.13).

Chen, Q.G., Bao, M.T., Fan, X.N., Liang, S.k., Sun, P.Y., 2013. Rhamnolipids enhance marine oil spill bioremediation in laboratory system. Mar. Pollut. Bull. 71, 269275.

China Academy of Transportation Science, 2013. Transport Science and Technology Information System. <http://www.transst.cn/PlatForm/Default.aspx> (accessed 18.12.13).

Crone, T.J., Tolstoy, M., 2010. Magnitude of the 2010 Gulf of Mexico oil leak. Science 330 (6004), 634

Department of Crime Control and Public Safety Division of Emergency Management, 2010. State of North Carolina Emergency Operations Plan. <http://www.NCCrimeControl.org> (accessed 18.10.13).

Eckle, P., Burgherr, P., Michaux, E., 2012. Risk of large oil spill: a statistical analysis in the aftermath of Deepwater Horizon. Environ. Sci. Technol. 46, 13002-13008.

Fingas, M., Brown, C., 2014. Review of oil spill remote sensing. Mar. Pollut. Bull. 83, $9-23$.
Garcia, D.A., Bruschi, D., Cumo, F., Gugliermetti, F., 2013. The Oil Spill Hazard Index (OSHI) elaboration. An oil spill hazard assessment concerning Italian hydrocarbons maritime traffic. Ocean Coast. Manage. 80, 1-11.

Garnacho, E., Law, R.J., Schallier, R., Albaiges, J., 2010. Targeting European R\&D for accidental marine pollution. Mar. Policy 34, 1068-1075.

Hassler, B., 2011. Accidental versus operational oil spills from shipping in the Baltic Sea: risk governance and management strategies. Ambio 40, 170-178.

Homan, A.C., Steiner, T., 2008. OPA 90's impact at reducing oil spills. Mar. Policy 32, 711-718.

Huang, B., Mao, D., Kang, Z., Cao, Y., Xiang, C., 2011. Synoptic and climatic characteristics of Yellow Sea fog and causation analysis. J. Trop. Meteorol. 27 (6), 920-929.

Huntington, H.P., Daniel, R., Hartsig, A., Harun, K., Heiman, M., Meehan, R., Noongwook, G., Pearson, L., Prior-Parks, M., Robards, M., Stetson, G., 2015. Vessels, risks, and rules: Planning for safe shipping in Bering Strait. Mar. Policy $51,119-127$.

International Maritime Organization, 1973. International Convention for the Prevention of Pollution from Ships. <http://www.imo.org/About/Conventions/ ListOfConventions/Pages/International-Conven-tion-for-the-Prevention-ofPollution-from-Ships-(MARPOL).aspx> (accessed 18.10.13).

International Maritime Organization, 1990. International Convention on Oil Pollution Preparedness, Response and Co-operation. <http://www.imo.org/ about/conventions/listofconventions/pages/intern-ational-convention-on-oilpollution-preparedness,-response-and-co-operation-(oprc).aspx> (accessed 18.10.13).

International Tanker Owners Pollution Federation Limited, 2011. Oil tanker spill statistics. <http://www.itopf.com/information-services/publications/ documents/STATSPACK2011.pdf> (accessed 18.12.13).

Jiang, J.P., Wang, P., Lung, W.S., Guo, L., Li, M., 2012. A GIS-based generic real-time risk assessment framework and decision tools for chemical spills in the river basin. J. Hazard. Mater. 227-228, 280-291.

Karahalios, H., 2014. The contribution of risk management in ship management: the case of ship collision. Saf. Sci. 63, 104-114.

Kingston, P., 2002. Long term environmental impact of oil spills. Spill Sci. Technol. Bull. 7 (1-2), 53-61.

Knapp, S., Velden, M., 2011. Global ship risk profiles: safety and the marine environment. Transp. Res. Part D - Transp. Environ. 16, 595-603.

Lao, H., Xu, S., Jiang, Y., 2009. Establishing our great wall at sea in the past 60 years: a review of the course for the development of China's oil spill emergency response system in the past 60 years. China Marit. Safe 9, 17-20.

Lin, S.C., Shih, Y.C., Chiau, W.Y., 2013. An impact analysis of destructive fishing and offshore oil barges on marine living resources in Taiwan Strait. Ocean Coast. Manage. 80, 119-131.

Liu, X., Meng, R.L., Xing, Q.G., Lou, M.J., Chao, H., Bing, L., 2015. Assessing oil spill risk in the Chinese Bohai Sea: a case study for both ship and platform related oil spill. Ocean Coast. Manage. 108, 140-146.

Lu, W., 2012. Action plan for the Northwest Pacific Ocean and establishing the institution of the regional sea. Dissertation, Nanjing University.

Luo, C., 2008. China's first aviation remote sensing monitoring system successfully for marine oil spill has been researched successfully. Pearl River Water Transp. 7, 54.

Marine Environmental Emergency Preparedness and Response Regional Activity Center, 2011. List of oil spill accidents. <http://merrac.nowpap.org/ activities/connector/13/excelOil/oilspill/all/list/1//and-nationCdSearch=CHINA > (accessed 18.12.13).

Maritime Safety Administration of China, 2012a. Oil spill emergency response seminar was opened successfully in Qingdao. <http://www.moc.gov.cn/zizhan/ zhishuJG/haishiju/guanlipindao/ gongzuodongtai/201206/ t20120619_ 1257434.html> (accessed 18.12.13).

Maritime Safety Administration of China, 2012b. List on ship pollution clean-up companies. <http://www.msa.gov.cn/Notice/Notice/e6f4c886-7889-486db500-8b1d76e-7f655> (accessed 18.12.13).

McEntire, D., Myers, A., 2004. Preparing communities for disasters: issues and processes for government readiness. Disaster Prevent. Manage. 13 (2), 140-152.

Ministry of Transport of China, 2008. Regulations on Configuration of National Marine Oil Spill Emergency Equipment Stockpiles. <http://www. baidu.com/link?url=KPTR_E6Y0-Y3wZnKiqdOvhen9xhzYFk_8S32mlWA4Ghhh n3JfCbcHEdTBrrorcJ5xYoeq039Ltwh49HsSsnc8NbU-4a> (accessed 18.12.13).

Ministry of Transport of China, 2009. Notices on Implementation Plan of Obsoleting Single-hulled Oil Tankers Domestic Voyage in Advance. <http:// www.moc.gov.cn/zizhan/zhish-ujigou/haishiju/guanlipindao/guanliwenjian/ 200912/t20091218_644448.html> (accessed 18.12.13).

Ministry of Transport of China, 2010. Implementing Measures on Civil Liability Insurance of Oil Pollution Damage from Ships. <http://www.gov.cn/flfg/201009/26/content_1-1709983.htm> (accessed 18.12.13).

Ministry of Transport of China, 2012. Report of China shipping development 2011. <http://www.gov.cn/gzdt/2012-07/31/content_2195266.htm> (accessed 18.12.13)

Ministry of Transport of China and Ministry of Finance of China, 2012. Regulations on the collection and used of oil pollution damage compensation fund by ships. <http://www.gov.cn /zwgk/2012-05/28/content_2147033.htm> (accessed 18.12.13).

Miraglia, R., 2002. The cultural and behavioral impact of Exxon Valdez oil spill on the native peoples of Prince William Sound, Alaska. Spill Sci. Technol. B 7 (1-2), $75-87$.

Mullin, J.V., Lane, J.S., 2000. R\&D users guide to the Ohmsett oil spill response test facility. Spill Sci. Technol. Bull. 6 (1), 77-87. 
National Development and Reform Commission of China and Ministry of Transport of China, 2007. Layout Planning of National Water Traffic Safety Supervision and Rescue System. <http://www.moc.gov.cn/zhuzhan/jiaotongguihua/ guojiaguihua/quanguojiaotong_HYGH/200710/t20071008_430004.html> (accessed 18.12.13).

National Natural Science Foundation of China, 2013. Internet-based Science information System. <http://isisn.nsfc.gov.cn/egrantindex/funcindex/ prjsearch-list> (accessed 18.12.13).

National People's Congress of China, 2000. Marine Environmental Protection Act of China. <http://www.gov.cn/ziliao/flfg/2005-08/05/content_2092-5.htm> (accessed 18.12.13).

Noh, S.R., Cheng H.K., Ha, M., Eom, S.Y., Kim, H., Choi, Y.H., Paek, D., 2015, Oxidative stress biomarkers in long-term participants in clean-up work after the Hebei Spirit oil spill. Sci. Total Environ. 515-516, 207-214.

Office of the Auditor General of Canada, 2010. Report of the Commissioner of the Environment and Sustainable Development to the House of Commons. <http:/ www.oag-bvg.gc.ca/internet/Englishh/osh_20101208_e_34597.html> (accessed 18.12.13).

Oil Spill Prevention and Response Net, 2012. List on emergency personnel. <http:/ www.osp.cn/> (accessed 18.12.13).

Otero, P., Ruiz-Villarreal, M., Allen-Perkins, S., Vila, B., Cabanas, J.M., 2014. Coasta exposure to oil spill impacts from the Finisterre Traffic Separation Scheme. Mar. Pollut. Bull. 85, 67-77.

Radović, J., Rial, D., Lyons, B.P., Harman, C., Viňas, L., Beiras, R., Readman, J.W. Thomas, K.V., Bayona, J.M., 2012. Post-incident monitoring to evaluate environmental damage from shipping incidents: chemical and biologica assessments. J. Environ. Manage. 109, 136-153.

Santos, C.F., Michel, J., Neves, M., Janeiro, J., Andrade, F., Orbach, M., 2013. Marine spatial planning and oil spill risk analysis: finding common grounds. Mar. Pollut. Bull. 74, 73-81.

Shi, J., 2012. The research of a large oil spill integrated remote sensing monitoring system in Bohai Sea. Dissertation, Dalian Maritime University.

Sinclair, H., Doyle, E.E., Johnston, D.M., 2012. Assessing emergency management training and exercises. Disaster Prev. Manage. 21 (4), 507-519.
Sivanesan, S., 2013. Oil spills - a disaster to the marine environment. Disaster Adv. 6 (2), 1-3.

State Council of China, 2004. The planning outline of marine economic progress in China. <http://www.cso.org.cn/ggxx/2013/0510/1129.html> (accessed 18.12.13).

State Council of China, 2010. Regulations on the Prevention and Controlling Marine Pollutions from Shipping. <http://www.gov.cn/flfg/2009-09/16/content_ 1418985.htm> (accessed 18.12.13).

State Environmental Protection Administration and Ministry of Transport of China, 2000. China Marine Ship Oil Spill Emergency Response Plan. <http://wenku. baidu.com-/view/0f6dc31c227916888486d7bf.html> (accessed 18.12.13).

Sydnes, A.K., Sydnes, M., 2013. Norwegian-Russian cooperation on oil-spill response in the Barents Sea. Mar. Policy 39, 257-264.

Wang, Z., Dong, H., 2010. U.S. Gulf oil spill emergency response, management measures and their implications. Int. Petrol. Econ. 6, 1-4.

Wei, L., Hu, Z.W., Dong, L., Zhao, W.J., 2015. A damage assessment model of oil spill accident combining historical data and satellite remote sensing information: a case study in Penglai 19-3 oil spill accident of China. Mar. Pollut. Bull. 91, 258-271.

Wirtz, K., Liu, X, 2006. Integrating economy, ecology, and uncertainty in an oil spill DSS: the Prestige accident in Spain 2002. Estuar. Coast Shelf Sci. 70, 525-532.

$\mathrm{Xu}, \mathrm{S}$., 2009. Do a better job for the country's marine pollution control and emergency response. China Mar. Safe 10, 37-40.

Xu, Q., Li, X.F., Wei, Y.L., Tang, Z.Y., Cheng, Y.C., Pichel, W.G., 2013. Satellite observations and modeling of oil spill trajectories in the Bohai Sea. Mar. Pollut. Bull. 71, 107-116.

Xu, L.L., Li, J., Brenning, A., 2014. A comparative study of different classification techniques for marine oil spill identification using RADARSAT-1 imagery. Remote Sens. Environ. 141, 14-23.

Zhang, Q., 2010. Study on ecological damage assessment model of marine oil spill. Dissertation, Ocean University of China.

Zhang, M., 2011. Analysis and countermeasures on marine pollution in China from oil transport. Chin. J. Environ. Manage. 2, 38-41.

Zhao, X., 2005. Research on the plan of response to oil pollution preparedness. Dissertation, Dalian Maritime University. 